\title{
Comparative Studies of Chemically Synthesized Polymers Aniline and o-Toluidine Nanocomposite Using Algerian Montmorillonite
}

\author{
Benyoucef Adelghani ${ }^{1}$, Yahiaoui Ahmed ${ }^{1}$, Hachemaoui Aicha ${ }^{1}$, \\ Sanchís Carlos ${ }^{2}$ and Morallon Emilia ${ }^{2}$ \\ ${ }^{1}$ Laboratoire de chimie organique, macromoléculaire et des matériaux, \\ Université de Mascara, \\ ${ }^{2}$ Departamento de Química Física e Instituto Universitario de Materiales, \\ Universidad de Alicante \\ ${ }^{1}$ Algeria \\ ${ }^{2}$ Spain
}

\section{Introduction}

Electronically conducting polymers have been the subject of numerous investigations in the past two decades (Nalwa, 1997a; Novak et al., 1997; Miller et al., 1997; Skotheim et al., 1998). These materials have properties that make them suitable for several applications including light-emitting diodes, sensors, batteries, and electrochemical supercapacitors. For the majority of these studies, a single polymer was prepared by chemical or electrochemical oxidation of the corresponding monomer. This as grown oxidized polymer is not pure and can be actually considered as a composite since counterions are included in the polymer matrix as dopant. On the other hand, the formation of copolymer displaying electronic conductivity has been much less investigated (Gningue et al., 1988; Laborde et al., 1990; Peters et al., 1992; Talu et al., 1996; Nalwa, 1997b; Sanchez De Pinto et al., 1997; Cha, 1997; San et al., 1998; Khalkali, 2005; Yildiz et al., 2006). The main motivation for preparing copolymer composites lies in the possibility that these materials will display better properties and also to overcome the limitation of the rareness of new conjugated $\partial$-bondcontaining monomers.

The preparation of copolymers from a pair of monomers will lead to an increase of the number of conductive polymers obtained from the same set of monomers (San et al., 1998). However, the main drawback of PANI is the limited $\mathrm{pH}$ range in which PANI retains its electrochemical activity. This is to some extend a function of the counter ion balancing the positive charge of the protonated emeraldine base (Lindfors et al., 2004, 2008). But usually PANI becomes insulating and electrochqemically inactive at $\mathrm{pH}$ above 4 (Diaz et al., 1980), which limits its use as a sensing platform for applications requiring neutral or alkaline electrolytes. Many approaches have been used to overcome this problem. These are based on (i) post-polymerization grafting of sulfonic groups onto PANI chains by fuming sulfuric acid treatment ( $\mathrm{Li}$ et al., 2005), copolymerization of parent aniline with $-\mathrm{COOH}$ or $-\mathrm{SO}_{3} \mathrm{H}$ 
functionalized aniline derivatives (Karyakin et al., 1994; Xu et al., 1997; Barbero et al., 2004; Benyoucef et al., 2010), or performing electropolymerization in the presence of various organic acids (Sun et al., 1998; Mu et al., 2002, 2003; Zhang et al., 2004, 2007; Barrios et al., 2006; Blomquist et al., 2009).

All these approaches, by introducing an ionogenic acidic group to the PANI structure, hinder the deprotonation of the conducting form of PANI (emeraldine) and thus extend its electroactivity toward less acidic pHs.

At the initial stages of the electrochemical polymerization, aniline is oxidized and becomes a radical cation, which leads to dimerization. The dimers of aniline, p-aminodiphenylamine (ADPA) as a dominant product along with benzidine and hydrazobenzene as minor products, are immediately oxidized and conjugated with aniline monomer. Polyaniline is formed on the electrode surface as a film by repeating this electrochemical process. However, the actual overall reaction seems to be more complicated, and the properties of the polymer formed by this method are changeable with the reaction conditions, such as applied potential, aniline concentration, $\mathrm{pH}$, and electrode material.

With regard to polyaniline based copolymers, a pioneering work has been done by Borole et al. (2004) and Wei et al. (1989, 1990). They have reported that aniline could be copolymerized with o-toludine to give rise to a copolymer film, of which conductivity could be controlled in a broad range. Copolymerization of aniline with N-butylaniline has been also reported (Bergeron et al., 1991). Copolymerization of aniline and o-toluidine by electrochemical and chemical method has been also studied (Dhawan et al., 1993). The resulting copolymer film found to have both good conductivity and solubility in common organic solvents. Lately, copolymerization of aniline with $\mathrm{N}$-methylaniline (Langer et al., 1993) and that with 3-aminophenyl-boric acid (Porter et al., 1990) have also been documented and also the electrochemical copolymerization of aniline with oaminobenzonitrile has been studied (Sato et al., 1994). These reports suggest that the copolymerization could provide us a convenient synthetic method to prepare new conducting materials with desired properties.

Here, we reported a preliminary spectroelectrochemical study of conducting polymers created using non-toxic cationic catalyst, known-as Magnhite- $\mathrm{H}^{+}$(Mag-H) (Yang et al., 1990; Belbachir et al., 2001). The polymerisation has been performed with aniline "polyaniline" and it has been extended to o-toluidine "poly(o-toluidine)" and copolymers of them. The properties of these polymers have been compared with those synthesized by bulk polymerisation. The relative reactivities are analyzed and the copolymers are characterized. The effect of the copolymer composition on polymer properties such as conductivity, UVvisible (UV-vis) and FT-IR spectroscopies, X-ray diffraction (XRD), Transmission electron micrographs (TEM), X-ray photoelectronic spectroscopy (XPS) and electrochemical response were evaluated.

\section{Experimental}

\subsection{Materials}

Aniline (from Aldrich) was distilled under vacuum prior to use and o-toluidine (from Aldrich) was used as received. Perchloric acid (from Merck) was suprapur quality and the water employed for the preparation of the solutions was obtained from an Elga Labwater Purelab Ultra system. A natural sodium montmorillonite clay (named as Maghnite) obtained from Tlemcen (Algeria) has been used 


\subsection{Catalyst structure}

Various methods of analysis, such as 27Al and 29Si MAS NMR, show that Maghnite is a montmorillonite silicate. The elementary analysis of the selected samples obtained using XRay Fluorescence (XRF) is presented in Table 1. Acid treatment of Raw-Maghnite was indicated to cause a relative reduction in the content of octahedrally spaced $\mathrm{Al}_{2} \mathrm{O}_{3}$ and a relative increase in silica $\left(\mathrm{SiO}_{2}\right)$.

\begin{tabular}{|l|l|l|l|l|l|l|l|l|l|l|}
\hline Sample & $\mathrm{SiO}_{2}$ & $\mathrm{Al}_{2} \mathrm{O}_{3}$ & $\mathrm{Fe}_{2} \mathrm{O}_{3}$ & $\mathrm{CaO}$ & $\mathrm{MgO}$ & $\mathrm{Na}_{2} \mathrm{O}$ & $\mathrm{K}_{2} \mathrm{O}$ & $\mathrm{TiO}_{2}$ & $\mathrm{SO}_{3}$ & $\mathrm{PF}^{*}$ \\
\hline Raw-Mag & 69.39 & 14.67 & 1.16 & 0.30 & 1.07 & 0.50 & 0.79 & 0.16 & 0.91 & 11 \\
\hline Mag-H & 71.70 & 14.03 & 0.71 & 0.28 & 0.80 & 0.21 & 0.77 & 0.15 & 0.34 & 11 \\
\hline
\end{tabular}

Table 1. Elementary compositions of Protons exchanged samples "Maghnite" (Compositions $w t \%) . P^{*}$ : Pert in Fire.

Table 2 shows the various types of montmorillonites studied, and it can be seen that Maghnite has 11.9 \% more $\mathrm{SiO}_{2}$ than Wyoming 19.35 and Montmorillon (Vienne, French) (Kerr et al., 1950; Damour et al., 1987). When treated with sulfuric acid, this difference is even greater; $14.21 \%$ and $21.66 \%$ as compared to Wyoming and Vienne Bentonite, respectively. Maghnite contains $5.60 \%$ and $5.49 \%$ less $\mathrm{Al}_{2} \mathrm{O}_{3}$, than the Wyoming and Vienne clay, respectively.

\begin{tabular}{|c|c|c|c|c|c|c|c|c|c|c|}
\hline Sample & $\mathrm{SiO}_{2}$ & $\mathrm{Al}_{2} \mathrm{O}_{3}$ & $\mathrm{Fe}_{2} \mathrm{O}_{3}$ & $\mathrm{FeO}$ & $\mathrm{CaO}$ & $\mathrm{MgO}$ & $\mathrm{Na}_{2} \mathrm{O}$ & $\mathrm{K}_{2} \mathrm{O}$ & $\mathrm{TiO}_{2}$ & $\mathrm{SO}_{3}$ \\
\hline $\begin{array}{c}\text { Wyoming } \\
\text { (USA) }\end{array}$ & 50.04 & 20.16 & 0.68 & 00 & 1.46 & 0.23 & $\mathrm{Tr}$ & 1.27 & 00 & 00 \\
\hline $\begin{array}{c}\text { Vienne } \\
\text { (Frensh) }\end{array}$ & 57.49 & 20.27 & 2.92 & 0.19 & 0.23 & 3.13 & 1.32 & 0.28 & 0.12 & 00 \\
\hline $\begin{array}{c}\text { Raw-Mag } \\
\text { (Algeria) }\end{array}$ & 69.39 & 14.67 & 1.16 & 00 & 0.30 & 1.07 & 0.5 & 0.79 & 0.16 & 0.91 \\
\hline $\begin{array}{c}\text { Mag-H } \\
\text { (Algeria) }\end{array}$ & 71.70 & 14.03 & 0.71 & 00 & 0.28 & 0.80 & 0.21 & 0.77 & 0.15 & 0.34 \\
\hline
\end{tabular}

Table 2. Composition in wt\% of American, French and Maghnia Algerian montmorillonite.

Fig. 1. shows the X-ray diffraction patterns of Raw-Maghnite and Mag- $\mathrm{H}^{+}$. The basal spacing of the Raw-Maghnite was $15.02 \AA$. The titration of Raw-Maghnite with $0.25 \mathrm{H}_{2} \mathrm{SO}_{4}$ resulted in the exchange of exchangeable cations for $\mathrm{H}^{+}$in the interlayer.

Damour et al. (1987), Kerr et al. (1950) and Kwon et al, (2001) reported that the decrease in the basal spacing indicates a loss of the interlayer water upon the replacement of $\mathrm{Na}^{+}$for $\mathrm{H}^{+}$. In particular, although the X-ray peak of the montmorillonite did not change substantially before or after the acid treatment, there was a decrease in the basal spacing. This implies that the original structure was well preserves after the acid treatment (Table 3).

The effects of the acid activation process on the FTIR spectrum of the treated Maghnite (Fig. 2) are summarised as follows: The intensity of the absorption band at $3630 \mathrm{~cm}^{-1}$ (Al-Al-OH coupled by Al-Mg-OH stretching vibrations) decreases with acid treatment. The bands at $3425 \mathrm{~cm}^{-1}$ and $3200 \mathrm{~cm}^{-1}$ (absorption of interlayer water) become more diffuse with acid treatment (Farmer, 1974). The intensity of the Si-O out of plane and Si-O-Si (2 bands) in plane stretching bands at 1116, 1043 and $999 \mathrm{~cm}^{-1}$ have not been affected by acid treatment. The Al-Al-OH $\left(920 \mathrm{~cm}^{-1}\right), \mathrm{AlFe}{ }^{3+} \mathrm{OH}\left(883 \mathrm{~cm}^{-1}\right)$ and $\mathrm{Al}-\mathrm{Mg}-\mathrm{OH}\left(846 \mathrm{~cm}^{-1}\right)$ deformation bands decrease with acid treatment. The intensity of the band at $796 \mathrm{~cm}^{-1}$ increases with treatment, reflects alterations in the amount of amorphous silica in accordance to the findings of others workers (Farmer 1979; Breen et al., 1995). The intensity of the band at $628 \mathrm{~cm}^{-1}$ (either Al-OH 
or Si-O bending and/or Al-O stretching vibration) gradually decreases with acid treatment in good agreement with the findings by Komadel, (2003). The intensity of the band at 467 $\mathrm{cm}^{-1}$ (Si-O-Al and Si-O-Mg coupled by $\mathrm{OH}$ vibration or Si-O bending vibrations) is essentially unchanged.

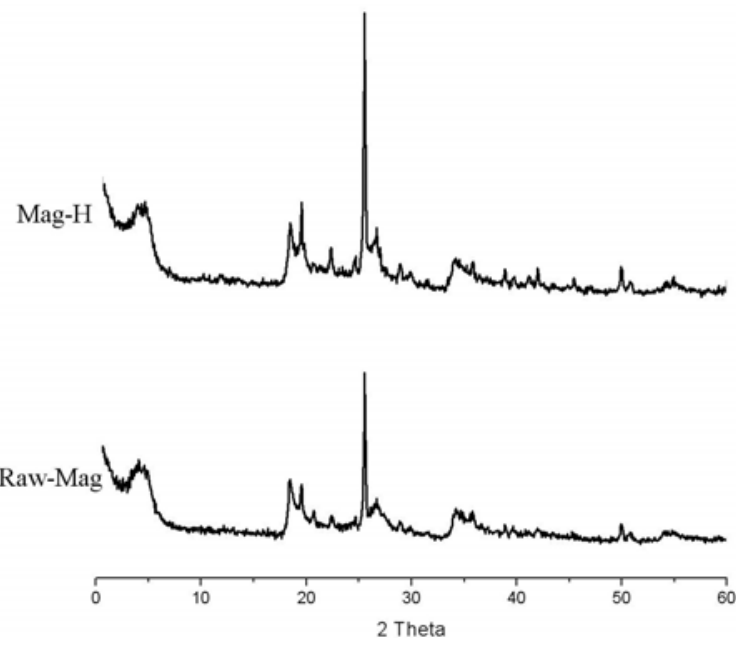

Fig. 1. X-ray Diffraction of Raw-Maghnite and Mag-H.

\begin{tabular}{|c|c|c|c|}
\hline Samples & dhkl $\left(\mathrm{A}^{\circ}\right)$ & Hkl & Nature of sample \\
\hline \multirow{5}{*}{ Raw-Mag } & 12.50 & 001 & Montmorillonite \\
\cline { 2 - 4 } & 4.47 & 110 & Montmorillonite \\
\cline { 2 - 4 } & 4.16 & $/ /$ & Quartz \\
\cline { 2 - 4 } & 3.35 & $/ /$ & Quartz \\
\cline { 2 - 4 } & 3.21 & $/ /$ & Feldspath \\
\cline { 2 - 4 } & 3.03 & $/ /$ & Calcite \\
\cline { 2 - 4 } & 2.55 & 200 & Montmorillonite \\
\cline { 2 - 4 } & 1.68 & 009 & Montmorillonite \\
\cline { 2 - 4 } & 1.49 & 060 & Montmorillonite \\
\hline \multirow{5}{*}{ Mag-H } & 15.02 & 001 & Montmorillonite \\
\cline { 2 - 4 } & 4.47 & 110 & Montmorillonite \\
\cline { 2 - 4 } & 4.16 & $/ /$ & Quartz \\
\cline { 2 - 4 } & 3.35 & $/ /$ & Quartz \\
\cline { 2 - 4 } & 3.21 & $/ /$ & Feldspath \\
\cline { 2 - 4 } & 3.03 & $/ /$ & Calcite \\
\cline { 2 - 4 } & 2.55 & 200 & Montmorillonite \\
\cline { 2 - 4 } & 1.68 & 009 & Montmorillonite \\
\cline { 2 - 4 } & 1.49 & 060 & Montmorillonite \\
\hline
\end{tabular}

Table 3. XRD characteristic of Raw-Maghnite and Mag-H. 
27Al NMR spectra of both Raw-Maghnite and Mag-H 0.25 M are given in Fig. 3. The spectra of Maghnite exhibits mainly the typical resonance at $2.9 \mathrm{ppm}$ of octahedral aluminium (6Al) in a phyllosilicate but also a small but significant contributions at 60 and $68 \mathrm{ppm}$ assigned to aluminium tetrahedrally co-ordinated to oxygen (4Al) (Samajovà et al., 1992; Benharrats et al., 2003).

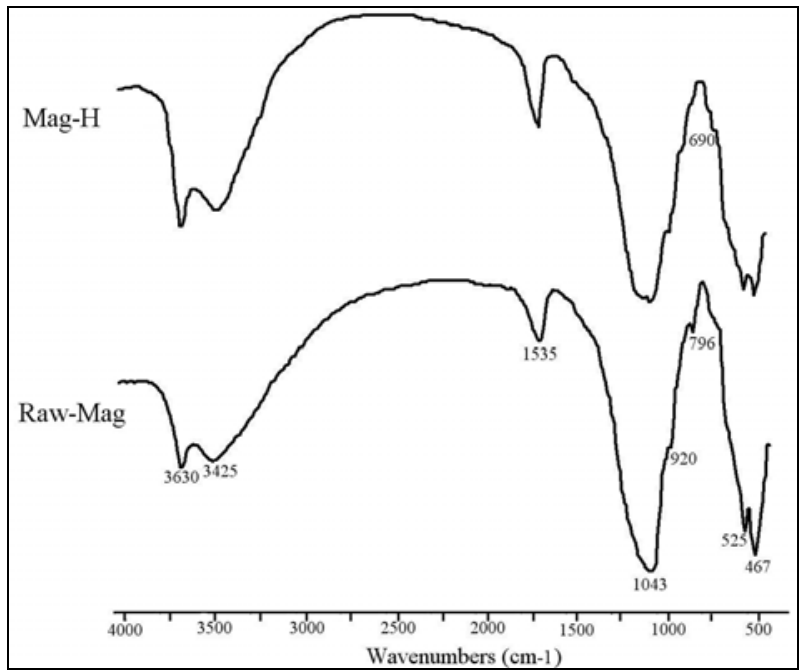

Fig. 2. IR Spectra of untreated Clay (Raw-Maghnite) and Acid treated Clay (Mag-H 0.25M).

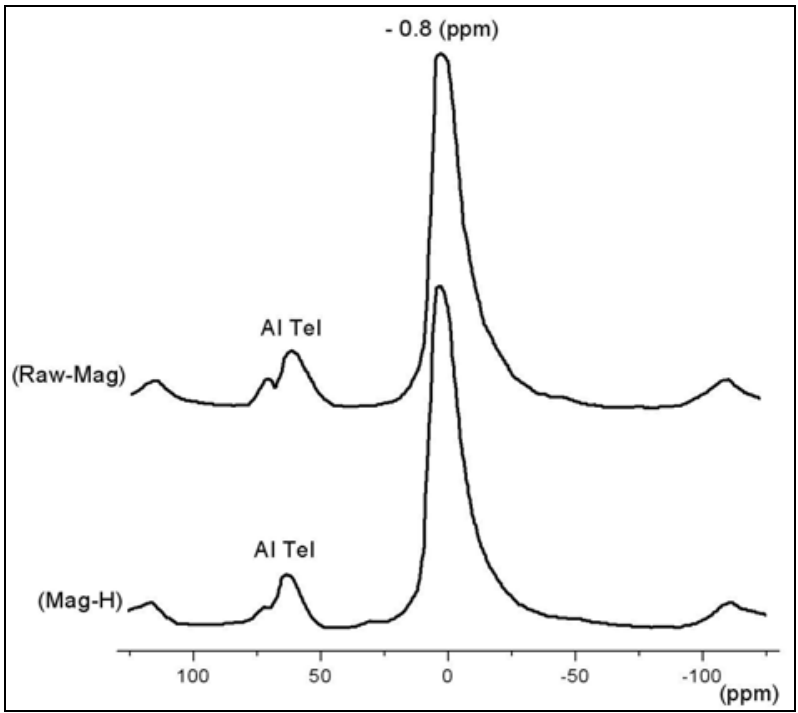

Fig. 3. 27Al MAS NMR spectra of Raw-Maghnite and Mag-H. 
The 29Si MAS NMR spectra for the Raw-Maghnite and Mag-H 0.25M are shown in Fig. 4. The dominant resonance at -93.5 ppm corresponds to Q3 (O-Al) units, i.e. SiO4 groups cross linked in the tetrahedral sheets with no aluminium in the neighbouring tetrahedral (Tkàc et al., 1994). The resonance at -112 ppm corresponds to three-dimensional (3D) silica with no aluminium present, designed Q4 (O-Al) (Tkàc et al., 1994; Kwon et al., 2001).

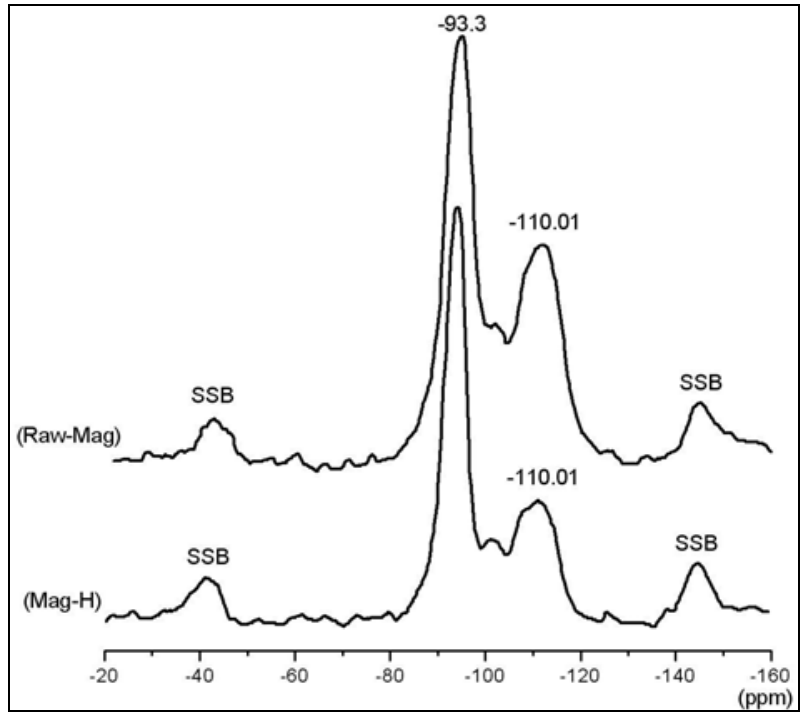

Fig. 4. 29Si MAS NMR spectra of Raw-Maghnite and Mag-H.

\subsection{Chemical synthesis}

To obtain the polymer, 0.022 moles of monomers (aniline and/or o-toluidine) was added to $1 \mathrm{~g}$ of the clay and the mixture was kept under magnetic stirrer at room temperature for 1 hour. The chemical polymerization began when $100 \mathrm{ml}$ of $0.1 \mathrm{M}$ ammonium persulfate solution was slowly added to the mixture (thus, the final concentration of aniline and otoluidine is $0.022 \mathrm{M}$ ). The reaction was carried out under magnetic stirring for 24 hours at room temperature and then the solid product was filtered under vacuum and washed with perchloric acid and distilled water to remove all traces of oxidant and oligomers. All the materials were dried at $60^{\circ} \mathrm{C}$. The polymers remain into the catalyst layers forming a polymer at the last of the synthesis. However, the Mag- $\mathrm{H}$ is easy to separate by filtration because it is insoluble in the solvents in which the polymers are soluble (Njopwouo et al., 1988).

The same procedure was used for the copolymer synthesis, keeping always the mass ratio Mag- $\mathrm{H} /$ monomers (aniline and/or o-toluidine were added with molar ratios: 20/80, 50/50 and $80 / 20$ to a total concentration of $0.22 \mathrm{M}$.) at 0.5 .

\subsection{Copolymer characterization}

The X-ray diffraction of the powder nanocomposites were taken using a Bruker CCD-Apex equipment with a X-ray generator ( $\mathrm{Cu} \mathrm{Ka}$ and $\mathrm{Ni}$ filter) operated at $40 \mathrm{kV}$ and $40 \mathrm{~mA}$. X-ray fluorescence spectroscopy of the powder nanocomposites was made using a Philips PW1480 
equipment with a UNIQUANT II software to determine elements in a semi quantitative way.

The XPS spectra were measured with a VG-Microtech Multilab electron spectrometer using non-monochromatised $\mathrm{Mg} \mathrm{K} \alpha(1253.6 \mathrm{eV})$ radiation from a twin anode source operated at $300 \mathrm{~W}(20 \mathrm{~mA}, 15 \mathrm{kV})$. Photoelectrons were collected into a hemispherical analyser working in the constant energy mode at pass energy of $50 \mathrm{eV}$. The binding energy (BE) of the Cls peak at $286.4 \mathrm{eV}$ was taken as internal standard. Peak analysis was done with mixed Gaussian/Lorentzian function lineshape by using the Peak-fit program implemented in the control software of the spectrometer. The pressure in the analysis chamber was always lower than $2.10^{-9}$ Torr. Thermal degradation of the samples does not occur because the time required to collect the XPS spectra is low.

The XPS measurements have been performed in the Mag-H/polymer samples. That is, the polymer has not been separated from the catalyst.

For recording the UV-Vis absorption spectra, a Hitachi U-3000 spectrophotometer was used. The solution of the copolymer in N-methyl-2-pyrrolidone (NMP) was used for recording the spectrum. Fourier transform infrared (FT-IR) spectroscopy was recorded using a Bruker Alpha.

For TEM experiments, the polymers were dispersed in water and then cast in TEM grids. The images were collected using a JEOL (JEM-2010) microscope, working at an operation voltage of $200 \mathrm{kV}$.

\subsection{Conductivity}

Conductivity measurements were carried out using a Lucas Lab resistivity equipment with four probes in-line. The samples were dried in vacuum during $24 \mathrm{~h}$; and pellets of $13 \mathrm{~mm}$ diameter were prepared using a FTIR mold by applying a pressure of $10 \mathrm{Tn} / \mathrm{cm}^{2}$.

\subsection{Electrochemistry}

The electrochemical behaviour of the polymers was studied by cyclic voltammetry after their extraction from the composite by dissolving in the N-methyl-2-pyrrolidone (NMP). It is known that this kind of conducting polymers is soluble in NMP (Yoshimoto et al., 2004; Sung et al., 2005), while the clay remains in solid state. Thus, both components can be separated by filtration. The electrochemical measurements were carried out using a conventional cell of three electrodes. The counter and reference electrodes were a platinum foil and a hydrogen reversible electrode (RHE) immersed in the same electrolyte, respectively. The working electrode was prepared as follows: after the polymer was extracted from the polymer using NMP, $50 \mu \mathrm{L}$ of this solution were cast over graphite carbon electrodes and the solvent evaporated to create polymeric films. The electrolyte used was $1 \mathrm{M} \mathrm{HClO}_{4}$ and all experiments were carried out at $50 \mathrm{mV} \mathrm{s}^{-1}$.

\section{Results and discussion}

\subsection{Copolymer characterization}

\subsubsection{XRD}

The Raw-Maghnite (Raw-Mag), the protonated Maghnite (Mag-H) and PoT/Mag-H nanocomposites were characterized using X-ray diffraction to check changes in the interlayer spacing (Fig. 5). The XRD patterns show that the (001) diffraction peak between $3.5^{\circ}$ and $5.5^{\circ}$ changes depending on the protonated and the polymer intercalated. 
Table 4. includes the d-spacing between the montmorillonite sheets calculated from the Bragg equation, the basal spacing and the maximum $2 \theta$ of the peaks; that expressed by law :

$$
n \lambda=2 d \sin \theta
$$

where $\lambda$ is the $\mathrm{X}$-ray wavelength, $d$ is the spacing between the atomic planes, and $\theta$ the angle between the X-ray beam and the atomic plane. Constructive interference occurs for integer values of $n$. By measuring $\theta$ for a known wavelength the Bragg spacing $d$ can be determined.

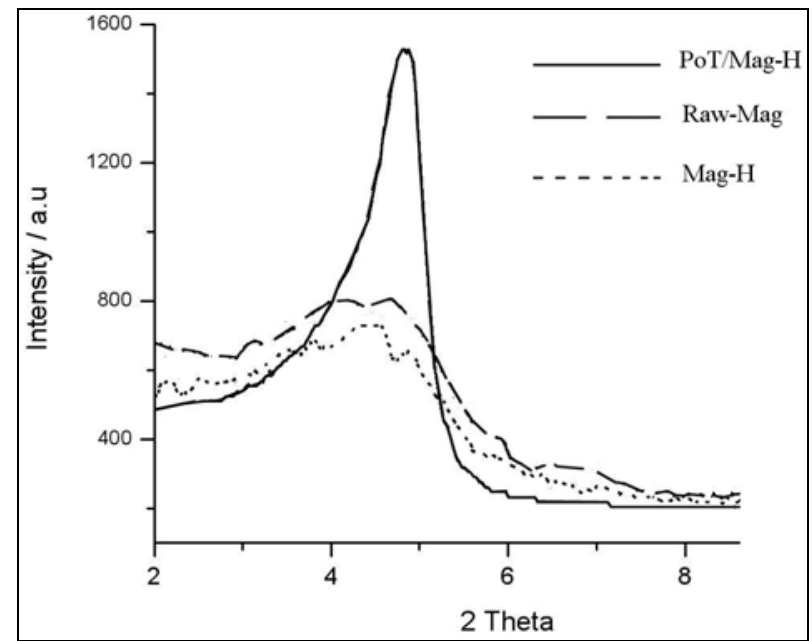

Fig. 5. XRD diffraction patterns of Raw-Maghnite and Protonated Maghnite (Mag-H) and PoT/Mag-H nanocomposite.

\begin{tabular}{|c|c|c|c|}
\hline Polymers & $\begin{array}{c}\text { Peak maximum, } \\
2 \theta \max (\mathrm{deg})\end{array}$ & $\begin{array}{c}\text { Basal spacing, } \\
d_{(001)}(\AA)\end{array}$ & $\begin{array}{c}\text { Interlayer spacing, } \\
\Delta d(\AA)\end{array}$ \\
\hline Raw-Mag & 4.5 & 13.4 & 3.5 \\
\hline Mag-H & 4.4 & 13.2 & 3.3 \\
\hline PoT/Mag-H & 4.9 & 14.1 & 4,6 \\
\hline $\begin{array}{c}\text { P(Ani-co-oT)/Mag-H } \\
(20-80 a)\end{array}$ & 4.8 & 13.9 & 4.5 \\
\hline $\begin{array}{c}\text { P(Ani-co-oT)/Mag-H } \\
(50-50 a)\end{array}$ & 4.9 & 13.9 & 4.6 \\
\hline $\begin{array}{c}\text { P(Ani-co-oT)/Mag-H } \\
(80-20 a)\end{array}$ & 4.8 & 14.1 & 4.5 \\
\hline
\end{tabular}

Table 4. Peak maximum and d-spacing of protonated and the nanocomposites intercalated into Raw-Maghnite. aFeed composition corresponding to aniline/o-toluidine ratio in the reactor.

\subsubsection{XPS}

Poly(o-toluidine), polyaniline and copolymer of them at different feed ratio (20/80, 50/50 and $80 / 20$ aniline/o-toluidine ratio) were obtained using the procedure described in the experimental section and characterized by X-ray photoelectronic spectroscopy (XPS). 
Fig. 6. shows the XPS spectra for poly(o-toluidine) synthesized using both the conventional and our method. The C1s signal for poly(o-toluidine) prepared using Mag-H (PoT/Mag-H) (Fig. 6a.) is practically identical to those obtained in perochloric acid (PoT/ $\left.\mathrm{HClO}_{4}\right)$ (Fig. 6b.). The C1s of poly(o-toluidine) can be deconvoluted into two peaks, the first one at $284.1 \mathrm{eV}$ is assigned to aromatic carbons. The peak at $285.8 \mathrm{eV}$ could be attributed to carbon atoms in quinonimine units and charged species (Chan et al., 1993; Belbachir et al., 2001) such as -C$\mathrm{N}^{+}$and $-\mathrm{C}=\mathrm{N}^{+}$. However, this peak could correspond also to carbon atoms on the methyl group.

The N1s signal for both PoT/Mag-H (Fig. 6c.) and $\mathrm{PoT} / \mathrm{HClO}_{4}$ (Fig. 6d.) can be deconvoluted into two principal peaks attributed at both neutral amino or imine groups $(399.2 \mathrm{eV})$ or positively-charged nitrogen atoms $(402 \mathrm{eV})$. In Table 5, the ratio between charged and neutral nitrogen atoms $\left(\mathrm{N}^{+} / \mathrm{N}\right)$ increases remarkably when a small quantity of aniline is added to the feed. In polyaniline substituted with anionic groups, the $\mathrm{N}^{+} / \mathrm{N}$ ratio is related to either the doping level or the charge localization (Chan et al., 1993; Salavagione et al., 2004) however, the increase of $\mathrm{N}^{+} / \mathrm{N}$ in this case is only related to the increase in the doping level because the substituting group $\left(-\mathrm{CH}_{3}\right)$ is not an ionic species and therefore it is unable to fix charge.

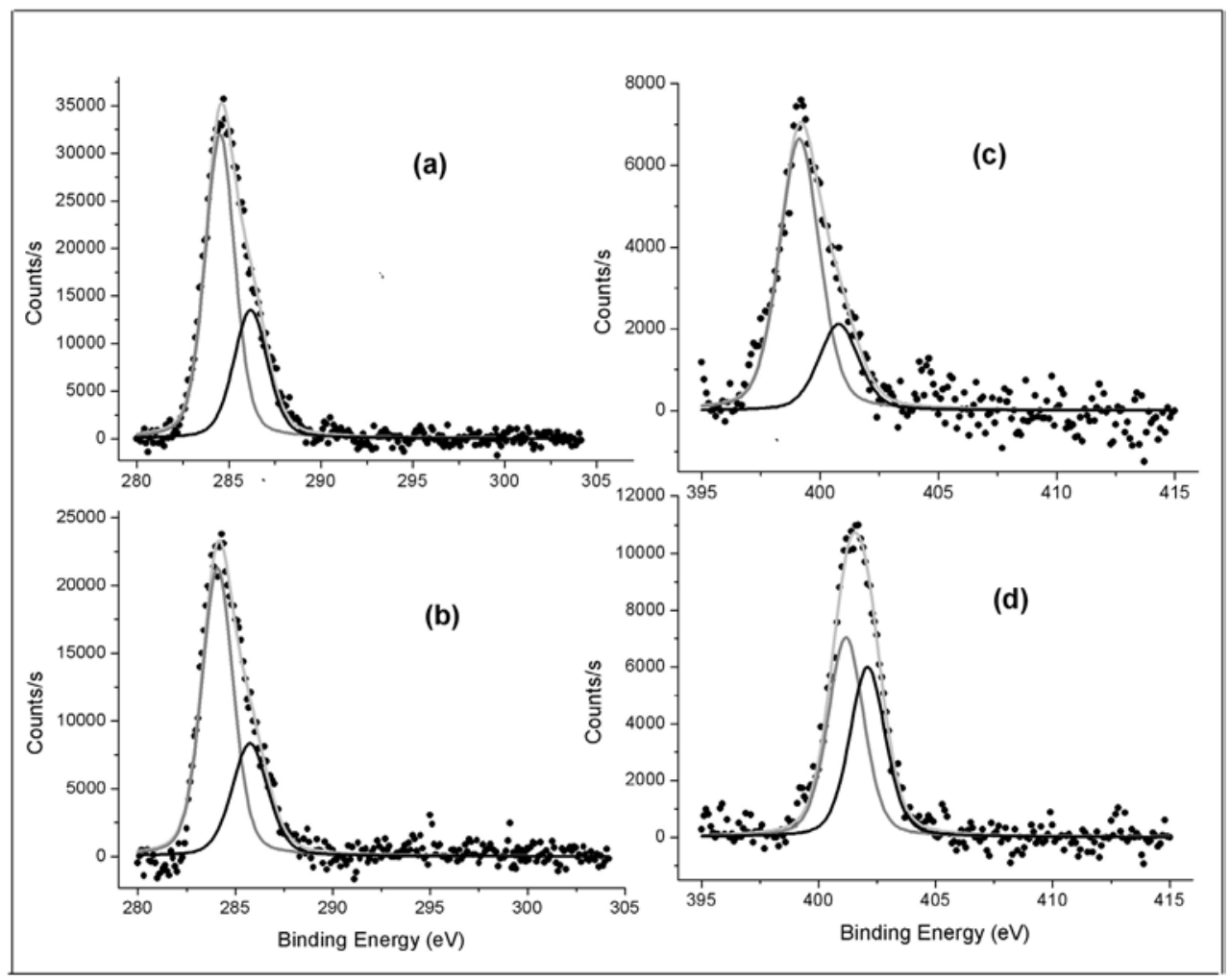

Fig. 6. XPS of poly(o-toluidine) for both $\mathrm{C} 1 \mathrm{~s}$ of $\mathrm{PoT} / \mathrm{Mag}-\mathrm{H}$ (a) and $\mathrm{PoT} / \mathrm{HClO}_{4}$ (b) and for N1s signal of PoT/Mag-H (c) and $\mathrm{PoT} / \mathrm{HClO}_{4}(\mathrm{~d})$. 
Table 5. shows the relative areas of de C1s peak for PoT and copolymers of aniline and otoluidine at different feed ratio. Here, it can be noted that while the area of the peak at 284.1 $\mathrm{eV}$ decreases when the amount of o-toluidine in the feed increase (column C1/C in Table 5); however, the area of the peak at $285.8 \mathrm{eV}$ increases (column C2/C in Table 5). Therefore, this signal at $285.8 \mathrm{eV}$ has contribution of carbon linked to the methyl group and the peak at $284.1 \mathrm{eV}$ only corresponds to carbon atoms in quinoneimine units.

\begin{tabular}{|c|c|c|c|}
\hline \multirow{2}{*}{ Polymers } & \multicolumn{2}{|c|}{ C1s Signal areas } & N1s Signal areas \\
\cline { 2 - 4 } & $\mathrm{C}_{1} / \mathrm{C}$ & $\mathrm{C}_{2} / \mathrm{C}$ & $\mathrm{N}^{+} / \mathrm{N}$ \\
\hline $\begin{array}{c}\mathrm{P}(\text { Ani-co-oT }) / \mathrm{Mag}-\mathrm{H} \\
\left(20-80^{a}\right)\end{array}$ & 0.626 & 0.374 & 0.486 \\
\hline $\begin{array}{c}\mathrm{P}(\text { Ani-co-oT }) / \mathrm{Mag}-\mathrm{H} \\
(50-50 a)\end{array}$ & 0.656 & 0.343 & 0.511 \\
\hline $\begin{array}{c}\mathrm{P}(\text { Ani-co-oT }) / \mathrm{Mag}-\mathrm{H} \\
(80-20 a)\end{array}$ & 0.684 & 0.315 & 0.666 \\
\hline $\mathrm{PoT} / \mathrm{MagH}^{\mathrm{P}} \mathrm{H}$ & 0.673 & 0.327 & 0.320 \\
\hline $\mathrm{PoT} / \mathrm{HClO}_{4}$ & 0.689 & 0.311 & 0.397 \\
\hline
\end{tabular}

Table 5. Areas of the XPS signal of C1s and N1s for homopolymers of o-toluidine and copolymer of them. C refers to total carbons area, C1 refers to BE $284.1 \mathrm{eV}$ and C2 correspond to $285.8 \mathrm{eV}$. aFeed composition corresponding to aniline/o-toluidine ratio in the reactor.

\subsubsection{FT-IR spectroscopy}

The FTIR spectra of homopolymers and copolymers are shown in Fig. 7. The spectral data of samples are in Table 6.

The FT-IR spectrum of PoT/Mag-H exhibits the following main spectral features (Kim et al., 1988; Gruger et al., 1994; Andrade et al., 1996) :

i. The broadband at $1580 \mathrm{~cm}^{-1}$ can be assigned to the C-C stretching mode combined with $\mathrm{C}=\mathrm{N}$ stretching vibrations of the quinoid rings.

ii. The band at $1496 \mathrm{~cm}^{-1}$ is attributed to the C-C stretching modes in the benzenoid units.

iii. The bands at $1325 \mathrm{~cm}^{-1}$ and $1223 \mathrm{~cm}^{-1}$ are assigned to the C-N stretching vibrations in the polymer chain.

iv. The band at $1158 \mathrm{~cm}^{-1}$ is related to the $\mathrm{C}=\mathrm{N}$ stretching mode; this band is a characteristic of doped PoT. It can be due to the doping of the PoT by the ambient gases.

v. The band at $1109 \mathrm{~cm}^{-1}$ can be attributed to charge delocalization on the polymer backbone.

vi. The band located at $804 \mathrm{~cm}^{-1}$ represents the paradisubstituted benzenoid rings in PoT. In addition, the presence of quinoid and benzenoid bands (1572 and $\left.1515 \mathrm{~cm}^{-1}\right)$ shows that the PoT is composed of imine and amine units. As can be seen, the spectra for both polymers are almost identical and show most of the bands of very similar conducting polymers (Sariciftci et al., 1990). 


\begin{tabular}{|c|c|c|}
\hline \multicolumn{2}{|c|}{ Wavenumber $\left(\mathrm{cm}^{-1}\right)$} & \multirow[b]{2}{*}{ Band characteristics } \\
\hline $\mathrm{PoT} / \mathrm{HClO}_{4}$ & $\begin{array}{l}\text { PoT/Mag- } \\
\mathrm{H}\end{array}$ & \\
\hline 579 & 582 & $\mathrm{C}-\mathrm{H}$ out of plane bending vibration \\
\hline 811 & 807 & $\begin{array}{l}\text { Paradisubstituted aromatic rings indicating polymer } \\
\text { formation }\end{array}$ \\
\hline 878 & 871 & Due to the methyl group attached to the phenyl ring \\
\hline 1109 & 1092 & $\mathrm{C}-\mathrm{H}$ in plane bending vibration \\
\hline 1160 & 1157 & Vibration band of the dopant anion \\
\hline 1315 & 1325 & $\begin{array}{l}\text { Aromatic } \mathrm{C}-\mathrm{N} \text { stretching indicating secondary aromatic } \\
\text { amine group }\end{array}$ \\
\hline 1496 & 1507 & $\mathrm{C}-\mathrm{N}$ stretching of benzenoid rings \\
\hline 1582 & 1578 & $\mathrm{C}-\mathrm{N}$ stretching of quinoid rings \\
\hline
\end{tabular}

Table 6. Characteristic frequencies of chemically synthesized poly(o-toluidine) synthitezed with $\mathrm{HClO}_{4}$ and with Mag-H.

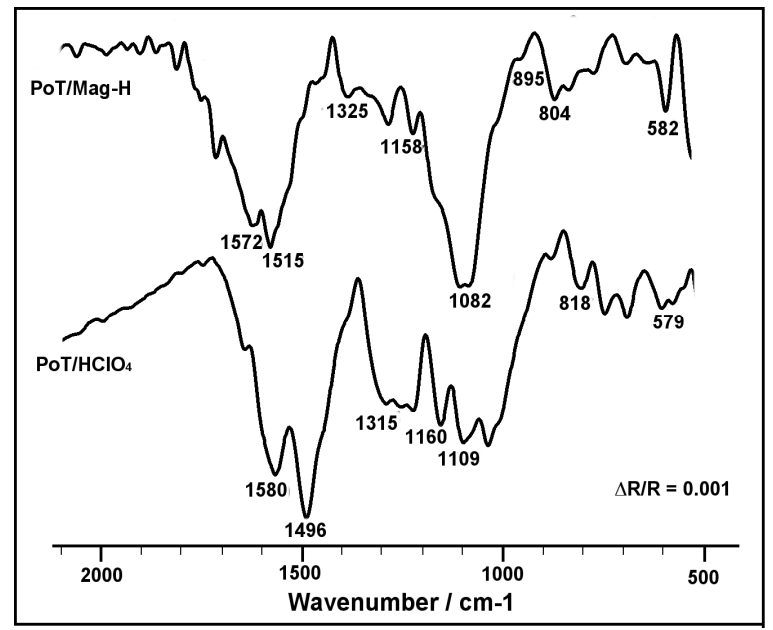

Fig. 7. FT-IR adsorption spectra of the of poly(o-toluidine) doped with Mag-H and with $\mathrm{HClO}_{4}$. 
The spectra of copolymer is shown in Fig. 8, they present features common to homopolymers synthesized using Mag- $\mathrm{H}$. In the spectra of copolymer appears absorption band at $1109 \mathrm{~cm}^{-1}$ (C-H bending) and $1496 \mathrm{~cm}^{-1}$ (C-C stretching) indicating the existence of methyl group in the copolymer; besides this, new absorption band appears at $1109 \mathrm{~cm}^{-1}$, which increases the intensity of the copolymer with increase of the o-toluidine content in the comonomer feed.

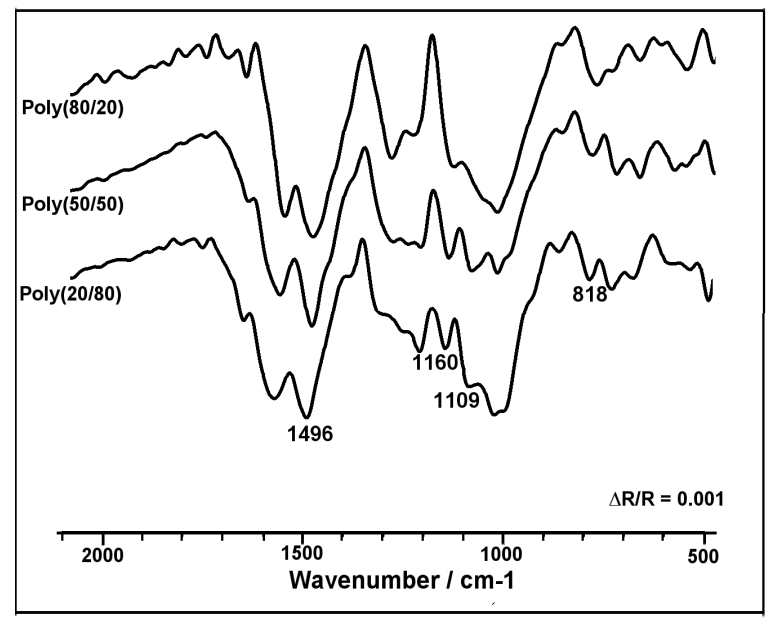

Fig. 8. FT-IR adsorption spectra of the copolymers with (aniline/o-toluidine) molar ratios $(20 / 80,50 / 50$ and $80 / 20)$.

\subsubsection{UV-Vis absorption measurement for the homo- and co-polymers}

The absorption maxima for the PoT/Mag-H, PoT/ $\mathrm{HClO}_{4}$ and poly(ANI-co-oT)/Mag-H in DMSO solution are given in Table 7, it is observed that, there are two absorption bands in the electronic spectra of homopolymers and copolymers (Fig. 9). The band around $310 \mathrm{~nm}$ is assigned to $\pi-\pi^{*}$ which corresponds to band gap and the band above $600 \mathrm{~nm}$ is assigned to $\mathrm{n}-\pi^{*}$ exciton band or inters band charge transfer associated with the excitation of benzenoid to quinoid rings (Chan et al., 1993; Yang et al., 2010).

\begin{tabular}{|c|c|c|}
\hline Polymers & $\begin{array}{c}\text { Bandgap } \\
\text { Adsorption } \\
\text { bands } \lambda_{\max }(\mathrm{nm})\end{array}$ & $\begin{array}{c}\text { Exciton } \\
\text { Adsorption } \\
\text { bands } \lambda_{\max }(\mathrm{nm})\end{array}$ \\
\hline $\begin{array}{c}\mathrm{P}(\text { Ani-co-oT)/Mag-H } \\
(20-80 \text { a })\end{array}$ & 311 & 596 \\
\hline $\begin{array}{c}\mathrm{P}(\text { Ani-co-oT)/Mag-H } \\
(50-50 \text { a })\end{array}$ & 316,5 & 599,5 \\
\hline $\begin{array}{c}\mathrm{P}(\text { Ani-co-oT }) / \mathrm{Mag}-\mathrm{H} \\
(80-20 \text { a })\end{array}$ & 307,5 & 597 \\
\hline PoT/MagH & 311,5 & 600,5 \\
\hline PoT/HClO 4 & 309 & 600 \\
\hline
\end{tabular}

Table 7. UV-Vis. absorption bands of polymers synthesized using Mag-H and $\mathrm{HClO}_{4} \cdot{ }^{a}$ Feed composition corresponding to (aniline/o-toluidine) ratio in the reactor. 


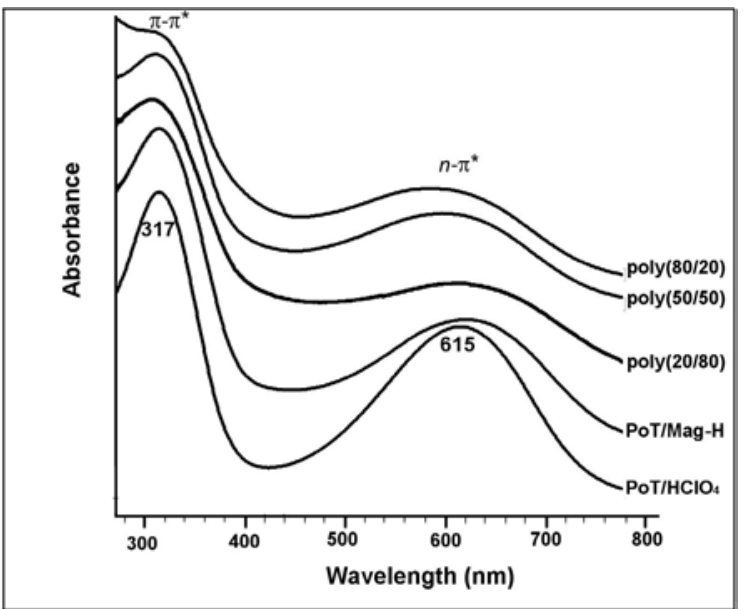

Fig. 9. UV-vis spectra of the poly(o-toluidine)/ $\mathrm{HClO}_{4}$ and poly(o-toluidine)/Mag-H.

The $\pi-\pi^{*}$ transistion of copolymers shows hyposochromic shift (blue shift). This may be due to the increase the degree of freedom and entropy of solvation. The $n-\pi^{*}$ exciton band shows a bathochromic shift (red shift) with an increase in dielectric constant of the solvent (Kim et al., 1988). The $\pi-\pi^{*}$ band in copolymer shifts to the lower wavelength (higher energy) as the mole percent of o-toluidine in copolymer increases, which may be due to addition of more o-toluidine unit, which twist the torsion angle, which is expected to increase the average bandgap in conjugated polymer chain.

\subsection{Copolymer properties}

\subsubsection{Conductivity}

The conductivities of homopolymers and copolymers are given in Table 8 . The values lie in between $2.19 \times 10^{-5}$ and $2.24 \times 10^{-3}{\mathrm{~S} . \mathrm{cm}^{-1}}^{-}$The conductivity of chemically synthesized $\mathrm{PoT} / \mathrm{HClO}_{4}$ salt show very low conductivity $\left(2.02 \times 10^{-3} \mathrm{~S}_{\mathrm{cm}}^{-1}\right)$ is higher than that of PoT/Mag-H salt $\left(2.19 \times 10^{-5}{\left.\mathrm{~S} . \mathrm{cm}^{-1}\right)}^{-}\right.$

\begin{tabular}{|c|c|}
\hline Polymers & Conductivity $\left({\left.\mathrm{S} . \mathrm{cm}^{-1}\right)}^{-1}\right.$ \\
\hline $\begin{array}{c}\mathrm{P}(\text { Ani-co-oT }) / \mathrm{Mag}-\mathrm{H} \\
(20-80 a)\end{array}$ & $2.24 \times 10^{-3}$ \\
\hline $\begin{array}{c}\mathrm{P}(\text { Ani-co-oT }) / \mathrm{Mag}-\mathrm{H} \\
\left(50-50^{a}\right)\end{array}$ & $1.52 \times 10^{-4}$ \\
\hline $\begin{array}{c}\mathrm{P}(\text { Ani-co-oT }) / \mathrm{Mag}-\mathrm{H} \\
(80-20 a)\end{array}$ & $6.26 \times 10^{-5}$ \\
\hline $\mathrm{PoT} / \mathrm{MagH}$ & $2.19 \times 10^{-5}$ \\
\hline $\mathrm{PoT} / \mathrm{HClO}_{4}$ & $2.08 \times 10^{-3}$ \\
\hline
\end{tabular}

Table 8. The conductivity values of polymers synthesized with $\mathrm{HClO}_{4}$ and Mag-H. ${ }^{a}$ Feed composition corresponding to (aniline/o-toluidine) ratio in the reactor. 
The conductivity of all the copolymers was found to be higher than that of the homopolymers PoT/Mag-H $\left(2.19 \times 10^{-5}{\mathrm{~S} . \mathrm{cm}^{-1}}^{-1}\right.$. The conductivity increases with aniline content. The higher conductivity of the copolymers compared to that of the PoT/Mag-H homopolymers indicates lowering of the band gap in the copolymers formed with toluidine (with a donor $-\mathrm{CH}_{3}$ group). This finding is supported by the bathochromic shift of the peak around $600 \mathrm{~nm}$ in the electronic absorption spectra of the copolymers as discussed later. However, the steric effect of the methyl group is likely to disrupt the overlapping of orbitals, hence lowering the degree of conjugation, by forcing the aromatic rings out of plane relative to each other. The poorer polaron formation of the copolymers with the higher concentration of o-toluidine is consistent with the conductivity decrease of copolymers. These results are reasonable because the self-doping degree must decrease as the aniline mole fraction increases. Therefore, we can conclude that all copolymers have some degree of self-doping despite the lower reactivity of o-touluidine monomer.

Also it is also possible that the addition of aniline in the ratio of copolymers curing affects the chain alignment of the polymer, which leads to the increase of conjugation length and that brings about the increase of conductivity.

\subsubsection{Solubility}

The solubility of PoT/Mag-H, PoT/ $\mathrm{HClO}_{4}$ and these copolymers of aniline/o-toluidine in different solvents are show in Table 9. The solubility decreases with increasing the concentration of aniline units in the copolymer. The solubility improvement of polymers prepared with Mag-H compared with $\mathrm{HClO}_{4}$ must be related to the presence of anionic and/or cationic groups (from the natural sodium montmorillonite clay units) in the synthesis of polymers.

\begin{tabular}{|c|c|c|c|c|c|c|c|c|c|c|}
\hline Samples & $\begin{array}{c}\mathrm{NH}_{4} \mathrm{O} \\
\mathrm{H}\end{array}$ & DMSO & THF & NMP & $\begin{array}{l}\text { Etha } \\
\text {-nol }\end{array}$ & $\begin{array}{l}\mathrm{CH}_{3} \mathrm{C} \\
\mathrm{OOH}\end{array}$ & $\begin{array}{c}\text { Tolue } \\
\text {-ne }\end{array}$ & $\begin{array}{l}\text { Acet } \\
\text {-one }\end{array}$ & $\mathrm{CCl}_{4}$ & $\mathrm{C}_{6} \mathrm{H}_{6}$ \\
\hline $\begin{array}{l}\mathrm{P}(\text { Ani-co- } \\
\text { oT)/Mag-H } \\
\left(20-80^{a}\right)\end{array}$ & S/BV & PS/BR & $\begin{array}{c}\text { PS/ } \\
\text { BG }\end{array}$ & $\begin{array}{c}\text { PS/ } \\
\text { BR }\end{array}$ & IS & PS/B & $\begin{array}{l}\text { PS/ } \\
\text { BG }\end{array}$ & $\begin{array}{l}\text { IS/ } \\
\text { BR }\end{array}$ & IS & IS \\
\hline $\begin{array}{c}\mathrm{P}(\text { Ani-co- } \\
\text { oT)/Mag-H } \\
\left(50-50^{a}\right)\end{array}$ & $\mathrm{S} / \mathrm{BV}$ & $\mathrm{S} / \mathrm{BV}$ & $\begin{array}{c}\text { PS/ } \\
\text { BR }\end{array}$ & $S / B R$ & $\begin{array}{c}\text { PS/ } \\
\text { BV }\end{array}$ & $\begin{array}{c}\text { PS/ } \\
\text { BG }\end{array}$ & IS & $\begin{array}{c}\text { PS/ } \\
\text { BR }\end{array}$ & IS & IS \\
\hline $\begin{array}{c}\mathrm{P}(\text { Ani-co- } \\
\text { oT)/Mag-H } \\
\left(80-20^{a}\right)\end{array}$ & $S / V$ & $\mathrm{~S} / \mathrm{BV}$ & $\begin{array}{l}\text { S/ } \\
\text { BR }\end{array}$ & S/BV & $\mathrm{PS} / \mathrm{B}$ & $\mathrm{S} / \mathrm{V}$ & IS & $\begin{array}{c}\text { PS/ } \\
\text { BR }\end{array}$ & $\begin{array}{c}\text { PS/ } \\
\text { B }\end{array}$ & IS \\
\hline PoT/MagH & $S / V$ & $\mathrm{~S} / \mathrm{BV}$ & $\begin{array}{l}\text { S/ } \\
\text { BV }\end{array}$ & $\mathrm{S} / \mathrm{BV}$ & $\begin{array}{c}\text { PS/ } \\
\text { BV }\end{array}$ & $S / V$ & IS & $\begin{array}{c}\text { PS/ } \\
\text { BR }\end{array}$ & $\begin{array}{c}\text { PS/ } \\
\text { B }\end{array}$ & IS \\
\hline $\mathrm{PoT} / \mathrm{HClO}_{4}$ & $\mathrm{~S} / \mathrm{V}$ & S/BR & $\begin{array}{c}\text { S/B } \\
R\end{array}$ & S/BR & $\begin{array}{l}\text { PS/ } \\
\text { RC }\end{array}$ & PS/B & IS & $\begin{array}{c}\text { PS/ } \\
\text { V }\end{array}$ & IS & IS \\
\hline
\end{tabular}

Table 9. Solubility of PoT/Mag-H, PoT/ $\mathrm{HClO}_{4}$ and copolymers (Aniline/o-Toluidine) in different solvents. Solubility in solvents (IS = Insoluble ; PS = Partially ; S : Soluble). The solution color is indicated in the parentheses with the following abbreviations (V : Violet ; BV : Bluish violet ; BR : Brownish red ; BG : Bluish green ; B : Blue).

The solubility of the resulting conducting polymer of (Aniline/o-Toluidine) increases with increasing the feed ratio of o-toluidine in the polymerization, and it was observed that the highest solubility gives a low conductivity. That is to say when the solubility decreases the 
conductivity increases. This result indicates the solubility of polymers synthesized with Mag-H decreased with increasing polymer chain.

\subsubsection{Electrochemical response}

To study the electrochemical response of polymers and copolymers, a conventional cell of three electrodes was used. To separate the polymers from the catalysts, they were dissolved in N-methyl-2-pyrrolidone (NMP). Films of the polymers were made by casting a drop of a solution of them in NMP over the electrode and heating with an infrared lamp to remove the solvent.

Fig. 10. shows the voltammograms obtained with the two electroactive poy(o-toluidine) films in $1 \mathrm{M} \mathrm{HClO}_{4}$ solution. The current densities have been normalized in order to clearly compare between the two polymers, due to the thickness of the films could vary from different samples. The electrochemical behaviour of the PoT/Mag-H exhibits two anodic peak around $0.48 \mathrm{~V}$ and $0.71 \mathrm{~V}$ however, on the reverse scan two reduction peaks around $0.59 \mathrm{~V}$ and $0.40 \mathrm{~V}$ are observed. This behaviour differs from those obtained when the polymer is created in acidic conditions (PoT/ $\mathrm{HClO}_{4}$, Fig. 10. continuous line). The polymer created in $\mathrm{HClO}_{4}$ shows the similar electrochemical response reported by Borole et al. $(2003,2004,2006)$, two pairs of redox peaks were detected with a potential shift at $0.58 / 0.37 \mathrm{~V}$ and $0.73 / 0.65 \mathrm{~V}$.

To try to clarify all peaks observed, we have synthesized polyaniline and copolymer of aniline/o-toluidine with Mag- $\mathrm{H}$ as proton source. The cyclic voltammogram of these copolymers obtained by Mag- $\mathrm{H}$ is shown in Fig. 11. The voltammetric behaviour of copolymer (aniline/o-toluidine) (20/80) is similar to those obtained in PoT/Mag-H. At higher concentration of aniline monomers (50/50), two pairs of anodic and cathodic current peaks are seen clearly, centred at around 0.51 and $0.80 \mathrm{~V}$. At lower electrode potentials, not exceeding $0.51 \mathrm{~V}$, the reduced (leucoemeraldine) form prevails, whereas at high potentials, exceeding ca. $0.80 \mathrm{~V}$, the fully oxidized (pernigraniline) form exists, leaving a broad potential window, ranging from 0.51 to $0.80 \mathrm{~V}$, where the conducting emeraldine form is most stable. In addition, for copolymers with high amounts of aniline (80/20) shows the same behaviour (tow redox process). Therefore, besides that the properties of this kind of conducting polymers do not depend on the type of anion used in the synthesis (Chan 1993), the electrochemical properties depend strongly on the proton source (inorganic acids or Mag-H catalyst).

\subsubsection{TEM}

Fig. 12. show the transmission electron micrographs of two typical polymers PoT/Mag-H and $\mathrm{PoT} / \mathrm{HClO}_{4}$. Transmission electron micrographs of the PoT/Mag-H reveal a structure similar to those of $\mathrm{PoT} / \mathrm{HClO}_{4}$. Presence of chopped fibers in the two polymers can be explained by considering the steric contribution of the methyl group. The methyl group present at the ortho position of the benzene ring leads to a distortion in the polymer chains and restrict the polymer growth in a linear fashion, which in turn results in a breakdown of the polymer chain into small fragments and this appears as small chopped or needle shaped fibers in the micrograph. Interestingly the polymer of PoT/Mag- $\mathrm{H}$ is more chopped fibers comprising of a whole polymer matrix than the corresponding $\mathrm{PoT} / \mathrm{HClO}_{4}$. The interplanar distances, however, do not exhibit any perceptible change with the two different methods of synthesis. The PoT/Mag-H apparently has larger interplanar distances than the corresponding $\mathrm{PoT} / \mathrm{HClO}_{4}$. 


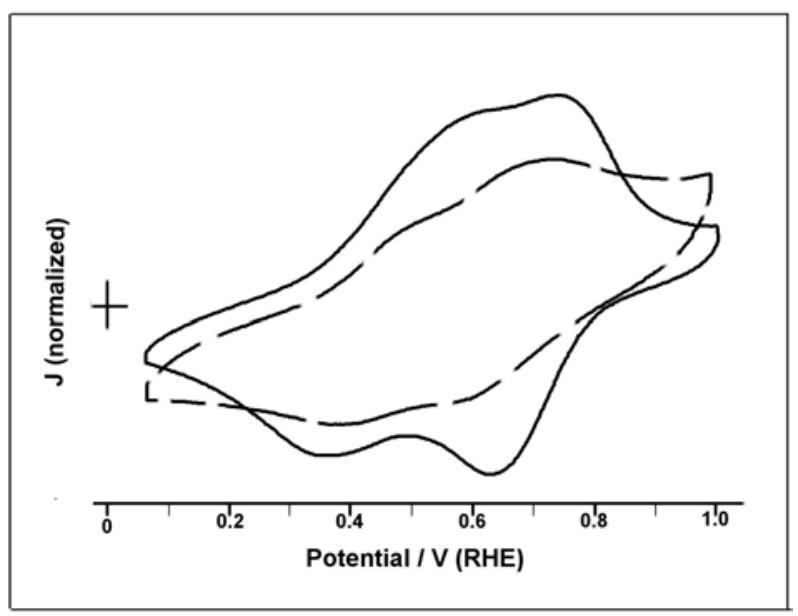

Fig. 10. Cyclic voltammograms recorded for a graphite electrode covered by PoT/Mag-H (dashed line) and $\mathrm{PoT} / \mathrm{HClO}_{4}$ (solid line) in $1 \mathrm{M} \mathrm{HClO}_{4}$ solution. Scan rate $50 \mathrm{mV} \mathrm{s}{ }^{-1}$.

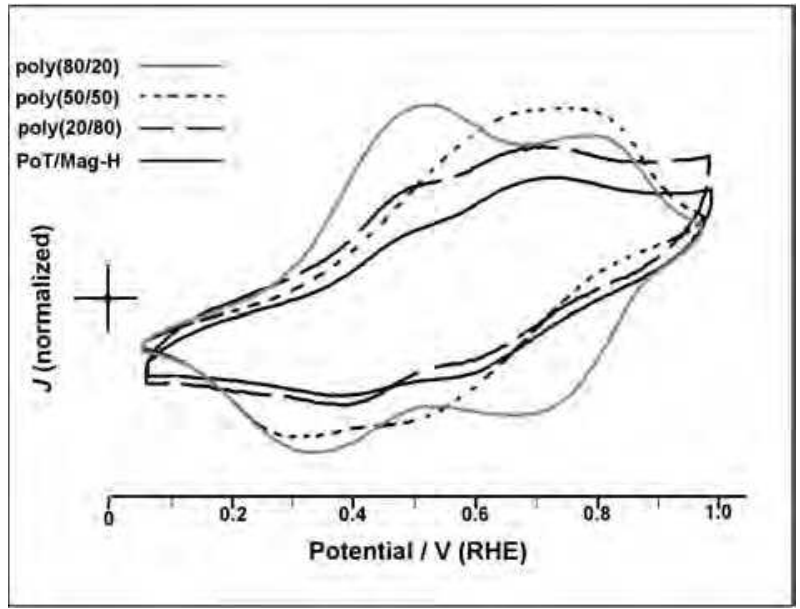

Fig. 11. Cyclic voltammograms recorded for a graphite carbon electrode covered by copolymers the feed ratio $\left(20 / 80,50 / 50\right.$ and $80 / 20$ aniline/o-toluidine ratio) in $1 \mathrm{M} \mathrm{HClO}_{4}$ solution. Scan rate $50 \mathrm{mV} \mathrm{s}^{-1}$. 

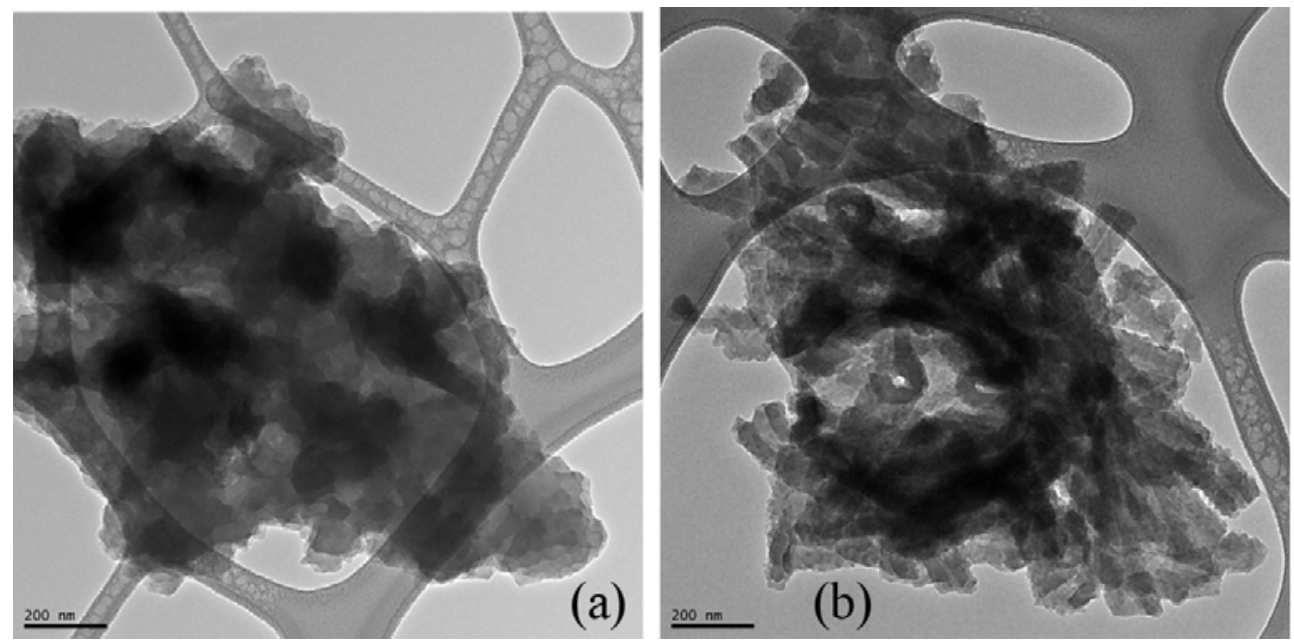

Fig. 12. Transmission electron micrographs (TEM) of poly(o-toluidine) doped with $\mathrm{HClO}_{4}$ $\left(\mathrm{PoT} / \mathrm{HClO}_{4}\right)(\mathrm{a})$ and doped with Mag-H (PoT/Mag-H) (b).

\section{Conclusions}

We have developed a new synthetic method to produce conducting polymers, which does not use inorganic acid but a non-toxic clay catalyst as proton source. Preliminary results about the spectroelectrochemical properties have been shown. However, we can conclude that the electrochemical behaviour of PoT/Mag-H is quite different from those observed for $\mathrm{PoT} / \mathrm{HClO}_{4}$. The polymers synthesized using Mag- $\mathrm{H}$ could show a structure that is a mixture of conducting (polyaniline-type) and redox (phenazine-type) units.

The degree of d-spacing of PoT/Mag-H nanocomposites was expanded to $4.6(\AA)$ compared to the Mag-H 3,3 $(\AA)$, this result shows the strong interaction between PoT and Mag-H that gives additional stability to the intercalated polymer within the matrix. The nanocomposite is having good conductivity, but less than that of pure PoT, due to the weakening in interchain interactions within the confined matrix. In addition, the PoT/Mag-H is more soluble in different solvents than $\mathrm{PoT} / \mathrm{HClO}_{4}$.

\section{Acknowledgements}

This work was supported by The National Agency for the Development of University Research (ANDRU), the Directorate General of Scientific Research and Technological Development (DGRSDT) of Algeria and the Departamento de Química Física e Instituto Universitario de Materiales, Universidad de Alicante (Spain).

\section{References}

Andrade, E. M. Molina, F. V. Florit, M. I. \& Posadas, D. (1996), Ir study of the first redox couple of poly(o-toluidine). anion involvement and potential dependence in strongly acidic solutions, Journal of Electroanalytical Chemistry, Vol.415, No.1-2, (October 1996), pp. 153-169, ISSN 1572-6657. 
Barbero, C. Salavagione, H.J. Acevedo, D.F. Grumelli, D.E. Garay, F. Planes, G.A. Morales, G.M. \& Miras, M.C. (2004),Novel synthetic methods to produce functionalized conducting polymers I. Polyanilines, Electrochimica Acta, Vol.49, No.22-23, (September 2004), pp. 3671-3686, ISSN 0013-4686.

Barrios, E. M. Mulica, G. A. \& Velasquez, C. L. (2006), Studies of the presence of dicarboxylic acids in the electrochemical synthesis of poly(aniline): Case poly(itaconic acid), Journal of Electroanalytical Chemistry, Vol.586, No.1, (January 2006), pp. 128-135, ISSN 1572-6657.

Belbachir, M. \& Bensaoula, A. (2001), Composition and Method for Catalysis using Bentonites, U.S. Patent, No. 7094823, (March 2002), ISBN 9780199751105, USA.

Benharrats, N. Belbachir, M. Legran, A. P. \& Déspinose de le Caillerie, J. B. (2003), 29Si and 27Al MAS NMR study of the zeolitization of kaolin by alkali leaching, Clay Minerals, Vol.38, No.1, (March 2003), pp.49-61, ISSN 0009-8558.

Benyoucef, A. Boussalem, S. Ferrahi, M.I. \& Belbachir, M. (2010), Electrochemical polymerizationa nd in situ FTIRS study of conducting polymers obtained from $o$ aminobenzoic with aniline at platinum electrodes, Synthetic Metals, Vol.160, No.1516, (August 2010), pp. 1591-1597, ISSN 0379-6779.

Bergeron, J.Y. \& Dao, L.H. (1991), Poly(aniline-co-N-butylaniline) copolymers. A new internal electrically conducting composite, Polym. Commun. Vol.32, No.13, (May 1991), pp. 403-404, ISSN 0263-6476.

Blomquist, M. Lindfors, T. Latonen, R.M \& Bobacka, J. (2009), Electropolymerization of Nmethylanthranilic acid and spectroelectrochemical characterization of the formed film, Synthetic Metals, Vol.159, No.1-2, (January 2009), pp. 96-102, ISSN 0379-6779.

Borole, D.D. Kapadi, U.R. Mahulikar, P.P. \& Hundiwale, D.G. (2003), Studies on electrochemical, optical and electrical conductivity characteristics of copolymer of polyaniline-co-poly(o-toluidine) using various organic salts, Materials Letters, Vol.57, No.22-23, (July 2003), pp. 3629-3635, ISSN 0167-577X.

Borole, D.D. Kapadi, U.R. Mahulikar, P.P. \& Hundiwale, D.G. (2004), Electrochemical behaviour of polyaniline, poly(o-toluidine) and their copolymer in organic sulphonic acids, Materials Letters, Vol.58, No.29, (November 2004), pp. 3816-3822, ISSN 0167-577X.

Borole, D.D. Kapadi, U.R. Mahulikar, P.P. \& Hundiwale, D.G. (2006), Electrochemical synthesis and characterization of conducting copolymer: Poly(o-aniline-co-otoluidine), Materials Letters, Vol.60, No.20, (Septembre 2006), pp. 2447-2452, ISSN 0167-577X.

Breen, C. Madejová, J. \& Komadel, P. (1995), Characterisation of moderately acid-treated, size-fractionated montmorillonites using IR and MAS NMR spectroscopy and thermal analysis, J. Materials Chemistry, Vol.5, No.3, (dec 1995), pp. 469-474. ISSN 1364-5501.

Cha, S.K.J. (1997), Electropolymerization rates of polythiophene/polypyrrole composite polymer with some dopant ions, Journal of Polymer Science Part B: Polymer Physics, Vol.35, No.1 (January 1997), pp. 165-172, ISSN 1099-0488

Chan, H.S.O. Ng, S.C. Sim, W.S. Tan, K.L. \& Tan, B.T.G. (1993), Synthesis and characterization of conducting poly(o-aminobenzyl alcohol) and its copolymers with aniline, Macromolecules, Vol.26, No.1, (January 1993), pp. 144-150, ISSN 00249297. 
Damour, A. \& Salvetat, D. (1987), Analyses sur un hydrosilicate d'alumine trouvé à Montmorillon. Annales de Chimie et Physique, Vol.3, No.21, (September 1993), pp. 376-383, ISSN 03651444.

Dhawan, S.K. \& Trivedi, D.C. (1993), Influence of polymerization conditions on the properties of poly(2-methylaniline) and its copolymer with aniline, Synthetic Metals, Vol.60, No.1, (September 1993), pp. 63-66, ISSN 0379-6779.

Diaz, A.F. \& Logan, J.A. (1980), Electroactive polyaniline films, Journal of Electroanalytical Chemistry, Vol.111, No.1, (April 1980), pp.111-114, ISSN 0022-0728.

Farmer, V.C. (1974), The Infrared Spectra of Minerals, Mineralogical Society, Farmer, V.C. (Ed), 427-485, Mineralogical Society Monograph 4, ISBN 13-978-0903056052. London, UK.

Farmer, V.C. (1979), Infrared spectroscopy, Pergamon Press, Van Olphen H. Fripiat, J.J. (Ed), 285-337, Data Handbook for Clay Materials and other Non-metallic Minerals, ISBN 0-56576-010-7, Oxford, UK.

Gningue, D. Horowitz, G. \& Garnier, F. J. (1988), Protection of CdSe Oxygen Photoanodes by Poly(bithiophene)-Polypyrrole Composites and Copolymers, J. Electrochem. Soc, Vol.135, No. 7, (July 1988), pp. 1695-1699, ISSN 1945-7111.

Gruger, A. Novak, A. Régis, A. \& Colomban, P. (1994), Infrared and Raman study of polyaniline Part II: Influence of ortho substituents on hydrogen bonding and UV/Vis-near-IR electron charge transfer, Journal of Molecular Structure, Vol.328, No.1, (December 1994), pp. 153-167, ISSN 0022-2860.

Karyakin, A.A. Strakhova, A.K. \& Yatsimirsky, A.K. (1994), Self-doped polyanilines electrochemically active in neutral and basic aqueous solutions.: Electropolymerization of substituted anilines, ,Journal of Electroanalytical Chemistry Vol.371, No.1-2, (June 1994), pp. 259-265, ISSN 1572-6657.

Kerr, P.F. Hamilton, P.K. \& Pill, R.J. (1950), Analytical data on reference, Clay Minerals: American Petroleum Institute Project 49, Clay Minerals Standards, preliminary report, Vol.7, No.160 (March 1950), pp. 92-98. ISSN 1572-4352,

Khalkali R.A. (2005), Electrochemical Synthesis and Characterization of Electroactive Conducting Polypyrrole Polymers Russian Journal of Electrochemistry, Vol.41, No.9 (September 2004), pp. 1071-1078, ISSN 1572-8838.

Kim, Y.H. Foster, C. Chiang, J. \& Heeger, A.J. (1988), Photoinduced localized charged excitations in polyaniline, Synthetic Metals. Vol.26, No.1, (October 1988), pp. 49-59, ISSN 0379-6779.

Komadel, P. (2003), Chemically modified smectites Clay Minerals, Clay Minerals, Vol.38, No.1, (March 2003), pp.127-138, ISSN 0009-8558.

Kwon, O.Y. Park, K.W. \& Jeong, S.Y. (2001), Preparation of Porous Silica-Pillared Montmorillonite: Simultaneous Intercalation of Amine-Tetraethylorthosilicate into H-Montmorillonite and Intra-Gallery Amine-Catalyzed Hydrolysis of Tetraethylorthosilicate, Bulletin of the Korean Chemical Society. Vol.22, No.7, (July 2001), pp. 678-686. ISSN 0253-2964.

Laborde, H. Leger, J.-M. Lamy, C. Garnier, F. \& Yassar, A. J. (1990), Electrocatalytic oxidation of hydrogen, formic acid and methanol on platinum modified copolymer (pyrrole-dithiophene) electrodes, Journal of Applied Electrochemistry, Vol.20, No.3, (May 1989), pp. 524-526, ISSN 1572-8838. 
Langer, J.J. (1993), N-substituted polyanilines: II. Photoacoustic and FT-IR spectra of poly(Nmethylaniline) and related copolymers, Synthetic Metals, Vol. 35, No.3, (April 1990), pp. 301-305, ISSN 0379-6779.

$\mathrm{Li}, \mathrm{C} . \mathrm{Mu}, \mathrm{S}$. (2005), The electrochemical activity of sulfonic acid ring-substituted polyaniline in the wide $\mathrm{pH}$ range, Synthetic Metals, Vol.149, No.2-3, (March 2005), pp. 143-149, ISSN 0379-6779.

Lindfors, T. \& Harju, L. (2008), Determination of the protonation constants of electrochemically polymerized poly(aniline) and poly(o-methylaniline) films, Synthetic Metals, Vol.158, No.8, (April 2008), pp. 233-241, ISSN 0379-6779.

Lindfors, T. Sandberg, H. \& Ivaska, A. (2004), The influence of lipophilic additives on the emeraldine base-emeraldine salt transition of polyaniline, Synthetic Metals, Vol.142, No.1-3, (April 2004), pp. 231-242, ISSN 0379-6779.

Miller, J. S. (1993), Conducting polymers-materials of commerce. Advanced Materials. Vol.5, No.7-8, (July/August 1993), pp. 587-589, ISSN 1521-4095.

$\mathrm{Mu}, \mathrm{S}$. \& Kan, J. (2002), The electrocatalytic oxidation of ascorbic acid on polyaniline film synthesized in the presence of ferrocenesulfonic acid, Synthetic Metals, Vol.132, No.1, (December 2002), pp. 29-33, ISSN 0379-6779.

$\mathrm{Mu}, \mathrm{S}$. (2003), The electrocatalytic oxidation of gallic acid on polyaniline film synthesized in the presence of ferrocene phosphonic acid, Synthetic Metals, Vol.139, No.2, (December 2003), pp. 287-294, ISSN 0379-6779.

Nalwa, H.S. (1997a), Handbook of Organic Conductive Molecules and Polymers, Conductive Polymers: Transport, Photophysics and Applications, ISBN 978-0-471-96275-5 Wiley, New York, USA.

Nalwa, H.S. (1997b), Handbook of Organic Conductive Molecules and Polymers, ISBN 978-0-47196275-5 Wiley, New York, USA.

Njopwouo, D. Roques, G. \& Wandji, R. (1988), A contribution to the study of the catalytic action of clays on the polymerization of styrene; II, Reaction mechanism, Clay Minerals, Vol.23, No.1, (March 1988), pp.35-43. ISSN 0009-8558.

Novak, P. Muller, K. Santhanam, K.S.V. \& Hass, O. (1997a), Electrochemically Active Polymers for Rechargeable Batteries, Chemical Reviews, Vol.97, No.01, (February 05), pp. 207-282, ISSN 1520-6890.

Peters, E.M. \& Van Dyke, J.D.J. (1992), Characterization of conducting copolymers of 2,2'bithiophene and pyrrole by cyclic voltammetry and UV/visible spectroscopy, Journal of Polymer Science Part A: Polymer Chemistry, Vol.30, No.9, (August 1992), pp. 1891-1898, ISSN 1099-0518.

Porter, T.L. Caple, G. \& Lee, C.Y. (1990), Structural study of the surface of aniline-3aminophenylboronic acid copolymer films, Synthetic Metals, Vol.46, No.1, (January 1992), pp. 105-112, ISSN 0379-6779.

Salavagione, H.J. Acevedo, D.A. Miras, M.C. Motheo, A.J. \& Barbero, C.A. (2004), Comparative study of 2-amino and 3-aminobenzoic acid copolymerization with aniline synthesis and copolymer properties, J. Polymer Science Part A: Polymer Chemistry, Vol.42, No.22, (November 2004), pp. 5587-5599, ISSN 1099-0518.

Samajovà, E. Kraus, I. \& Lajcàkovà, A. (1992), Diagenetic alteration of miocene acidic vitric tuffs of the jastraba formation, Geologica Carpathica Clays. Vol.1, No.1, (Mai 1992), pp.21-26, ISSN 1210-2695 
San, B. \& Talu, M. (1998), Electrochemical copolymerization of pyrrole and aniline, Synthetic Metals, Vol.94, No.2, (April 1998), pp. 221-227, ISSN 0379-6779.

Sanchez De Pinto, M.I. Mishima, H.T. \& López De Mishima, B.A.J. (1997), Polymers and copolymers of pyrrole and thiophene as electrodes in lithium cells, Journal of Applied Electrochistry, Vol.27, No.7, (May 1996), pp. 831-838, ISSN 1572-8838.

Sariciftci, N.S. Kuzmany, H. Neugebauer, H. \& Neckel, A. (1990), Structural and electronic transitions in polyaniline: A Fourier transform infrared spectroscopic study, Journal of Chemical Physics, Vol.92, No.7, (March 1989), pp. 4530-4540, ISSN 0021-9606.

Sato, M. Yamanaka, S. Nakaya, J. \& Hyodo, K. (1994), Electrochemical copolymerization of aniline with o-aminobenzonitrile, Electrochimica Acta, Vol.39, No.14, (October 1994), pp. 2159-2167, ISSN 0013-4686.

Skotheim, T.A. Elsenbaumer, R.L. \& Reynolds, J.R. (1998), Handbook of Conducting Polymers, ISBN 0824757424, Marcel Dekker, New York, USA.

Sun, J.J. Zhou, D.M. Fang, H.Q. \& Chen, H.Y. (1998), The electrochemical copolymerization of 3,4-dihydroxybenzoic acid and aniline at microdisk gold electrode and its amperometric determination for ascorbic acid, Talanta, Vol.45, No.5, (March 1998), pp. 851-856, ISSN 0039-9140.

Sung, J.H. \& Choi, H.J. (2005), Effect of pH on Physical Characteristics of Conducting Poly(oEthoxyaniline) Nanocomposites, Journal of Macromolecular Science, Part B, Vol.44, No.3, (Feb 2007), pp. 365-375, ISSN 1520-5738.

Talu, M. Kabasakaloglu, M. \& Oskoui, R.H.J. (1996), Electrochemical copolymerization of thiophene and aniline, Journal of Polymer Science Part A: Polymer Chemistry, Vol.34, No.14, (October 1996), pp. 2981-2989, ISSN 1099-0518.

Tkàc, I. Komadel, P. \& Müeller, D. (1994), Acid-treated montmorillonites; a study by 29Si and 27Al MAS NMR, Clay Minerals, Vol.29. No.1, (March 1994), pp.11-19, ISSN 0009-8558.

Wei, Y. Focke, W.W. Wnek, G.E. Ray, A. \& MacDiarmid, A.G. (1989), Synthesis and electrochemistry of alkyl ring-substituted polyanilines, Journal of Physical Chemistry, Vol.93, No.1, (January 1989), pp. 495-499, ISSN 1932-7447.

Wei, Y. Hariharan, R. \& Patel, S.A. (1990), Chemical and electrochemical copolymerization of aniline with alkyl ring-substituted anilines, Macromolecles, Vol.23, No.3, (February 1990), pp. 758-764, ISSN 1520-5835.

Xu, J.J. Zhou, D.M. Chen, H.Y. \& Fang, H.Q. (1997), Amperometric determination of ascorbic acid at a novel 'self-doped' polyaniline modified microelectrode, Journal of Analytical Chemistry, Vol.362, No.2, (February 1998), pp. 234-238, ISSN 1608-3199.

Yang, O. Zhang, Y. Li, H. Zhang, Y. Liu, M. Luo, J. Tan, L. Tang, H. \& Yao, S. (2010), Electrochemical copolymerization study of $o$-toluidine and $o$-aminophenol by the simultaneous EQCM and in situ FTIR spectroelectrochemisty, Talanta, Vol.81, No.12, (April 2010), pp. 664-672, ISSN 0039-9140.

Yildiz, H.B. Kiralp, S. Toppare, L. Yagci, Y. \& Ito, K. (2006), Synthesis of conducting copolymers of thiophene capped poly(ethylene oxide) with pyrrole and thiophene, Materials Chemistry and Physics, Vol.100, No.1, (November 2006), pp. 124-127, ISSN 0254-0584.

Yoshimoto, S. Ohashi, F. \& Kameyama, T. (2004), Simple Preparation of Sulfate AnionDoped Polyaniline-Clay Nanocomposites by an Environmentally Friendly 
Mechanochemical Synthesis Route, Macromolecular Rapid Communications, Vol.25, No.19, (October 2004), pp. 1687-1691, ISSN 1521-3927.

Zhang, L. \& Dong, S. (2004), The electrocatalytic oxidation of ascorbic acid on polyaniline film synthesized in the presence of camphorsulfonic acid, Journal of Electroanalytical Chemistry, Vol.586, No.1, (July 2004), pp. 189-194, ISSN 15726657.

Zhang, L. (2007), The electrocatalytic oxidation of ascorbic acid on polyaniline film synthesized in the presence of $\beta$-naphthalenesulfonic acid, Electrochimica Acta, Vol.52, No.24, (August 2007), pp. 6969-6975, ISSN 0013-4686. 


\section{InTech Europe}

University Campus STeP Ri

Slavka Krautzeka 83/A

51000 Rijeka, Croatia

Phone: +385 (51) 770447

Fax: +385 (51) 686166

www.intechopen.com

\section{InTech China}

Unit 405, Office Block, Hotel Equatorial Shanghai

No.65, Yan An Road (West), Shanghai, 200040, China

中国上海市延安西路65号上海国际贵都大饭店办公楼 405 单元

Phone: +86-21-62489820

Fax: +86-21-62489821 
(C) 2012 The Author(s). Licensee IntechOpen. This is an open access article distributed under the terms of the Creative Commons Attribution 3.0 License, which permits unrestricted use, distribution, and reproduction in any medium, provided the original work is properly cited. 